\title{
The origins of the arts council movement; philanthropy and policy
}

\section{Roger Blomgren}

To cite this article: Roger Blomgren (2018): The origins of the arts council movement; philanthropy and policy, International Journal of Cultural Policy

To link to this article: https://doi.org/10.1080/10286632.2018.1547381

\section{曲 Published online: 19 Nov 2018.}

Submit your article to this journal

View Crossmark data \ulcorner 


\section{BOOK REVIEW}

\section{The origins of the arts council movement; philanthropy and policy, by Anna} Rosser Upchurch, UK, Palgrave Macmillan, 2016, XII, 214 pp., 96, $29 €$ (hardcover), ISBN 978-1-137-46162-9, 74, 96 € (ebook), ISBN 978-1-137-46163-6

This book examines the history and ideas of arts advocacy that underlie the national arts policies of the UK, Canada and the USA. The author, who sadly passed away in 2016, has carried out an essential work in exploring and identifying the roots of the foundations of Art councils and the idea of the Arm's Length Principle (ALP), and how these ideas influenced policy models in the three countries. The book consists of earlier articles, mainly from the International Journal of Cultural Policy, which have been rewritten and expanded.

It was not the author's ambition, fortunately, to discover a universal causal model by arguing that Art Council Movements are a result of capitalism, globalisation or neoliberalism or any other explanatory, reductionist type of model, which is quite common among cultural policy researchers. Nor does she take an outspoken case study approach, aiming to explain different structural or institutional settings or actors on the policy level or aim to conduct an administrative analysis of the policy model and explain different outputs of and impacts on cultural policy. Instead, the author focuses on the history of the people involved in the establishment of cultural policy in Great Britain and later in Canada and the USA and on the ideas and values embedded in such a policy model. This approach makes this work more exciting and provides an essential contribution to the history of cultural policy and cultural policy research. There has been a lack of thorough, empirically based research in this field where ideas and the role of individuals are highlighted as significant factors in explaining policy changes.

The author's starting point was to investigate how and why the arts council policy model was conceived, and why it is widespread as an organisational model in the USA. Three significant questions come into focus. The first question concerns who influenced the shift in responsibility for art funding from private philanthropy to the state in Great Britain and Canada during the middle of the twentieth century. The second question takes up the issue of why the main actors chose to get involved? What ideas did they have about arts in society and did those ideas influence arts policy? What argument did they use to justify state involvement? Finally, the last question concerns if and how such ideas informed art policy in the USA?

These questions indicate that by reading this work, we will get a detailed study and examination of ideas and the role of different policy actors that have not been thoroughly explored or acknowledged in the historiography of cultural policy. Policy historians have explained the shift from private philanthropy to public sources for arts funding in Great Britain by arguing that this was a result of the welfare state expansion in the 1940s. This explanatory model is also standard in explaining the breakthrough in Nordic countries for cultural policy as a welfare state project. Examination of how specific ideas and people influenced this breakthrough is still underdeveloped in the Nordic countries.

In order to trace central individuals and ideas, the author starts in Great Britain, the country where the roots of arts policy are to be found and where the discussion about the role of society for 'real' arts and 'real' artists was initiated at the beginning of the last century. Upchurch identifies central individuals and groups in order to explore their motivations, ideologies and working methods.

The first chapter presents very personal biographies of three philanthropists, intellectuals and policy advisors. Two men, John Maynard Keynes in Great Britain and Vincent Massay in Canada are the individuals most associated with the establishment of the art council model in their countries. Dorothy Elmhirst was influential in the USA. These three were selected for historical and conceptual 
reasons: Keynes represents the intellectual who influenced policy-making, while Massey and Elmhirst demonstrate the role of wealthy aesthetes and philanthropists, who were also active in making policy recommendations for national funding agencies.

In the following chapter, essential ideas that influenced these three people, as well as the concept of the clerisy, are analysed and discussed as they evolved in England in the nineteenth and twentieth century. Massey and Elmhirst shared ideas about social responsibility, which motivated them to use their wealth for solving social problems. Keynes was foremost influenced by ideas of social engineering, that through rational intellectual reasoning solutions could be found to social problems.

Keynes is the central focus in the book, probably because he is the most prominent and the first to outspokenly advocate cultural policy by formulating new ideas and personally taking responsibility for implementing these ideas in the Arts Council in Great Britain. It is interesting to read about his engagement in the Bloomsbury group which significantly impacted on his ideas about society and the arts, and it inspired him to implement art policy in Great Britain. This group had outspoken ideas about intellectual freedom, love, beauty in art and nature as being intrinsically good. These idealistic conceptions of art were influenced by the prominent philosopher G.E. Moore in his book Principia Ethica. In chapter three these ideas about art and society in the first part of the 20th century are examined in more depth together with ideas that influenced the intellectual debate and in particular, Keynes, Massey and Elmhirst.

In the following four chapters, the author discuss how these ideas were implemented in the three countries. In chapter four, arts policy during the Second World War in the UK is taken up and how art was accorded an important role in defending civilisation from non-civilized or barbarian ideas during this period. The formation of national cultural infrastructures for the decades to come is also discussed. This is followed by a chapter about the foundation of the Arts Council, which is also called 'Keynes's Legacy', indicating his central role as an important policy maker. These chapters are followed by chapters about Canadian Cleary and Canada Council and a minor chapter about the Art council movements in the USA. As the name indicates, the state does not take the same responsibility in the USA as in the other two countries.

The ideas and individuals in focus in these chapters are treated as 'independent variables' emphasising how they matter in creating policy in the three countries. We are allowed to follow these three people closely in their activities and their roles in policy formation. Upchurch identifies and explores their motivations, ideologies and their methods of gaining support and legitimacy for their ideas. Formal policy and legislative actions are often, as the author shows, the final steps in a long process of meetings, conversations and informal exchanges among alliances of individuals. The reader is led into good, interesting, challenging and new insights about what lay behind the formation of the Arts Councils and their role and organisation in the three countries. In these chapters, Keynes' role in formulating cultural policy is also in focus as his ideas influenced both Canada and the USA. The author might have expanded and developed the chapters on Canada and the USA, especially the chapter about the Arts Councils Movements in the USA. However, it is doubtful if we can arrive at any profound answer to the question of how the ideas about the movements influenced art policy in the USA. It is foremost a story about art policy in Great Britain and that is good enough.

Upchurch asks in the final chapter what we can learn 'about art policy formation in a period before professionals - special advisors, lobbyists, think-tanks, and consultants - dominated the process?' (p. 204). By reading the book, profound insights are provided about the legacy of a privileged small group or class with advantages of wealth and education, in this case, philanthropists and intellectuals, and how their collaboration gave rise to art policy that still influences cultural policy in our time. Art policy was foremost an elite project that dominated cultural policy during this period; it was not masses of working-class people demanding more high culture in society. Other researchers have also recognised this dominance of the cultural elite in both Arts Councils' boards and in the public who visit high culture events. Besides elite domination, the author explicitly points out the gendered process of early policymaking in the arts. This elite was nearly all male and well-educated, especially in the UK and Canada. Here Dorothy Elmhirst is an exception. 
This book is an excellent example of what in historical institutionalism is called Path dependency analysis; even if Upchurch has not explicitly carried out this type of research. In path dependency analysis, ideas are traced as a means of explaining underlying causals factors driving formative moments or policy changes. Upchurch has made a significant contribution to cultural policy research in describing the factors that influenced Arts Councils' ideas and the Arm's length principle. These concepts are still highlighted today by cultural policy researchers and are considered essential or as having an idiomatic value that is taken for granted, used to identify the specific constitution of cultural policy. In the cultural field, these kinds of ideas are interpreted as natural, normative assumptions implying that politicians should steer as little as possible. Upchurch's contribution is to explain these ideas in conjunction with the people behind the formation of the modern cultural policy and to discuss the story of these concepts. Researchers of today have much to learn from Upchurch's book and her methodology in tracing the roots of concepts.

My only criticism, apart from wishing that there was more depth in the chapter about the USA, is that sometimes Upchurch becomes entirely normative in her acknowledgement of cultural policy in Great Britain. In the last chapter, she writes: 'Now is the time to increase public spending on the arts in local communities, to work for cultural rights, and to give citizens means to live flourishing lives on their terms.' (p. 209). As a reader, this type of statement makes you wonder if the author has had any critical views of the subjects of her study and not only idolised Keynes and the Art Council Movements.

However, this objection can be seen as a minor remark. The main contribution is, apart from deepening our knowledge of cultural policy, the thorough and detailed examinations of finding both the roots of and the ideas behind policy and discussing their impact. Upchurch points out that ideas and individuals, not only structural variables, matter in this policy area. Her book has not only something to offer the cultural policy researcher but even students, artists, cultural policymakers and people who are interested in cultural policy history.

Roger Blomgren Library and Information Science, University of Borås

Q roger.blomgren@hb.se

(c) 2018 Roger Blomgren https://doi.org/10.1080/10286632.2018.1547381 